\title{
Reliability-Oriented Design of a Solar-PV Deployments
}

\author{
Paweł Kut ${ }^{1, *(D)}$, Katarzyna Pietrucha-Urbanik ${ }^{2, *(D)}$ and Barbara Tchórzewska-Cieślak ${ }^{2}$ (D) \\ 1 Department of Heat Engineering and Air Conditioning, Faculty of Civil, \\ Environmental Engineering and Architecture, Rzeszow University of Technology, \\ Al. Powstancow Warszawy 6, 35-959 Rzeszow, Poland \\ 2 Department of Water Supply and Sewerage Systems, Faculty of Civil, \\ Environmental Engineering and Architecture, Rzeszow University of Technology, \\ Al. Powstancow Warszawy 6, 35-959 Rzeszow, Poland; cbarbara@prz.edu.pl \\ * Correspondence: p.kut@prz.edu.pl (P.K.); kpiet@prz.edu.pl (K.P.-U.)
}

Citation: Kut, P.; Pietrucha-Urbanik,

K.; Tchórzewska-Cieślak, B.

Reliability-Oriented Design of a Solar-PV Deployments. Energies 2021, 14, 6535. https://doi.org/10.3390/ en14206535

Academic Editors: Eduardo F. Fernández and Ignacio Mauleón

Received: 1 August 2021

Accepted: 7 October 2021

Published: 12 October 2021

Publisher's Note: MDPI stays neutral with regard to jurisdictional claims in published maps and institutional affiliations.

Copyright: (c) 2021 by the authors. Licensee MDPI, Basel, Switzerland. This article is an open access article distributed under the terms and conditions of the Creative Commons Attribution (CC BY) license (https:// creativecommons.org/licenses/by/ $4.0 /)$.

\begin{abstract}
Increasing restrictions on the emission of greenhouse gases by the standards and the European Union's policy aims at increasing the share of renewable energy sources in the energy mix of the Member States. Subsequently, we observe a rapid increase in the installed capacity of the renewable energy sources. Renewable energy sources are currently the fastest growing sectors of energy generation, specifically the photovoltaic sector. In 2005, the total installed capacity in photovoltaic installations in the European Union was about 2.17 GW, while in 2019 it was already over $130 \mathrm{GW}$. Currently, due to many forms of incentive governmental measures the construction of photovoltaic installations is rapidly increasing with installations mounted on private houses and buildings. The article presents selected issues concerning the failure modes of photovoltaic installations and a comparative assessment of the estimated and the real measured electrical production of an operational photovoltaic installation. The Solar-PV power plant design approach proposed in the paper considers the failure modes to enhance the plant's reliability.
\end{abstract}

Keywords: energy; design; numerical; simulations; failure

\section{Introduction}

The continuous development of modern society creates an ever increasing demand of electricity, since the WW-II. Satisfying this growing demand relying only on fossil fuels such as coal or oil is not a sustainable clean energy option, as fossil fuels are depleted and cause pollution [1,2]. Resource depletion and increasing pollution are major threats to the modern society. Renewable energy sources present a formidable opportunity to sustain the continuous development of the modern society and to dissipate the threats induced by the fossil energy [3].

Figure 1 shows the percentage share of renewable energy in the total energy production in the European Union in 2005-2019. Within 14 years, the share of renewable energy has doubled, from $10 \%$ in 2005 to almost 20\% in 2019. Sweden has the highest percentage of renewable energy among the Member States of the European Union. In 2019, 56.4\% of Sweden's energy was produced using renewable energy sources (hydropower, wind, photovoltaic and biofuels). Of all European countries, including those not belonging to the European Union, Iceland has the highest percentage share of renewable energy-78.2\% (hydropower and geothermal). 


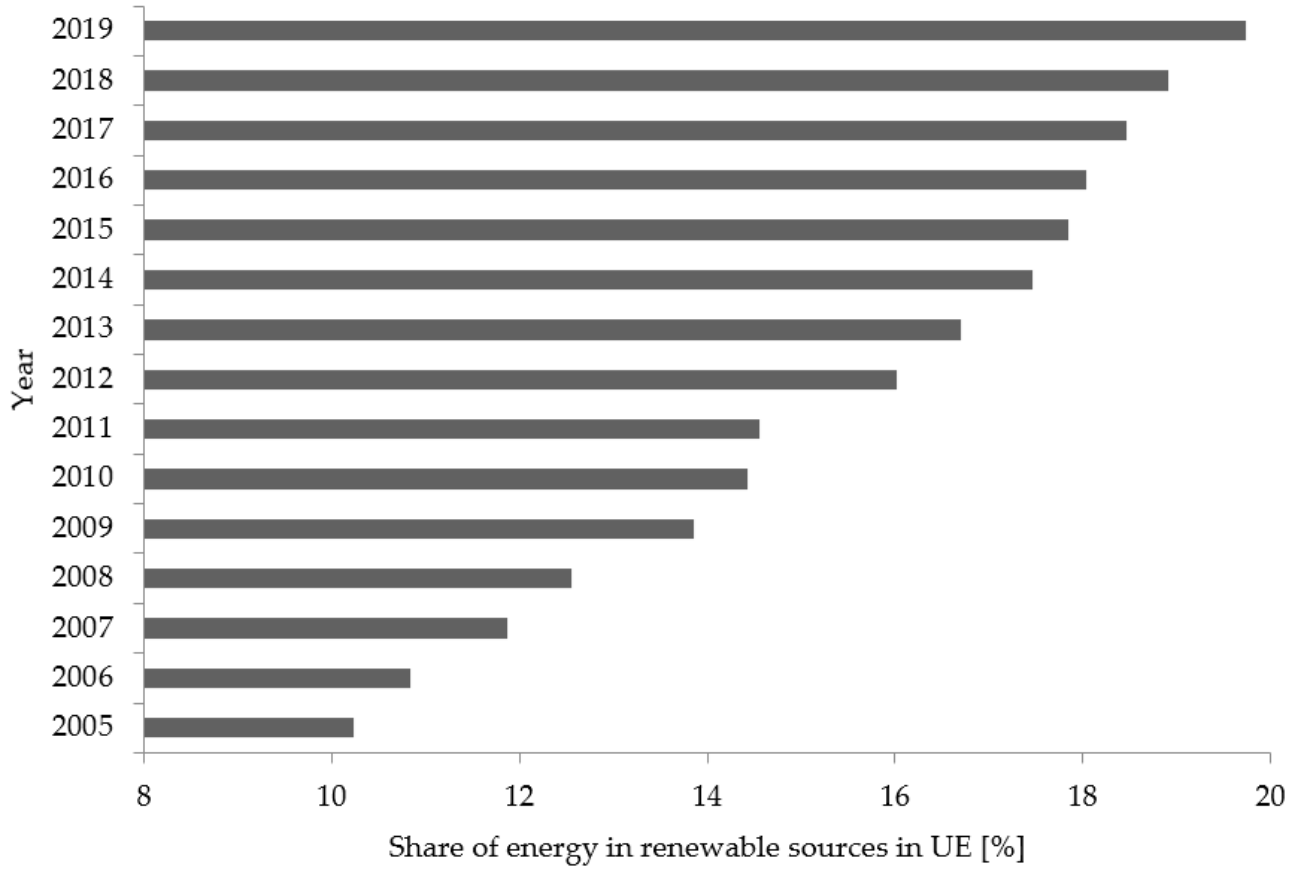

Figure 1. Share of renewable energy in the total energy production in the European Union in 2005-2019. Adapted from Ref. [4].

According to Directive 2009/28/EC of the European Parliament and the European Council, the aim for 2020 was to achieve a $20 \%$ share of renewable energy in total energy production and a $10 \%$ share of renewable sources in EU transport sectors. In order to achieve a $20 \%$ share of renewable energy in the total energy production in the European Union, individual Member States have set up specific targets that should be achieved by 2020. Figure 2 shows the targets set up by specific Member States and their degree of fulfilment in 2019. Sweden, Finland, Slovakia, Romania, Lithuania, Latvia, Cyprus, Italy, Greece, Estonia, Denmark, the Czech Republic and Bulgaria have already met the targets. Portugal, Austria, Hungary and Germany were close to meeting the targets in 2019 (less than $1 \%$ to meet the target).

Despite the fact that many countries may not have achieved the required target, the total share of renewable energy in the European Union has achieved its target of $20 \%$ share in energy production. The next step will be to improve energy efficiency by 2030. The goals set for the Member States will be: reducing greenhouse gas emissions by at least $40 \%$ compared to 1990 , increasing the share of renewable energy sources to $32 \%$ and increasing energy efficiency by at least $32.5 \%$.

Stand-alone photovoltaic systems are the most economic and ecological power generation solutions for both remote places from the power grid and in cities where connection to the grid is associated with high installation connection costs.

The use of a stand-alone photovoltaic system for power supply is particularly beneficial for various types of lighting and emergency telephones on highways, navigation buoys, lighthouses, telecommunications relay stations or weather stations. Energy from stand-alone photovoltaic systems is clean, quiet and reliable energy.

The EU 2020 Climate \& Energy package targeted an increase in the share of renewable energy sources up to $20 \%$ in EU countries [5]. Therefore, investments in renewable energy sources are necessary [6-14]. Solar energy is a major renewable source to generate electricity through photovoltaic cells [15-17]. Due to various types of subsidies, a large increase in installed capacity in photovoltaic installations has been recorded [18]. Figure 3 shows a rapid increase in the photovoltaic installed capacity in the European Union in the period 2005-2019. 


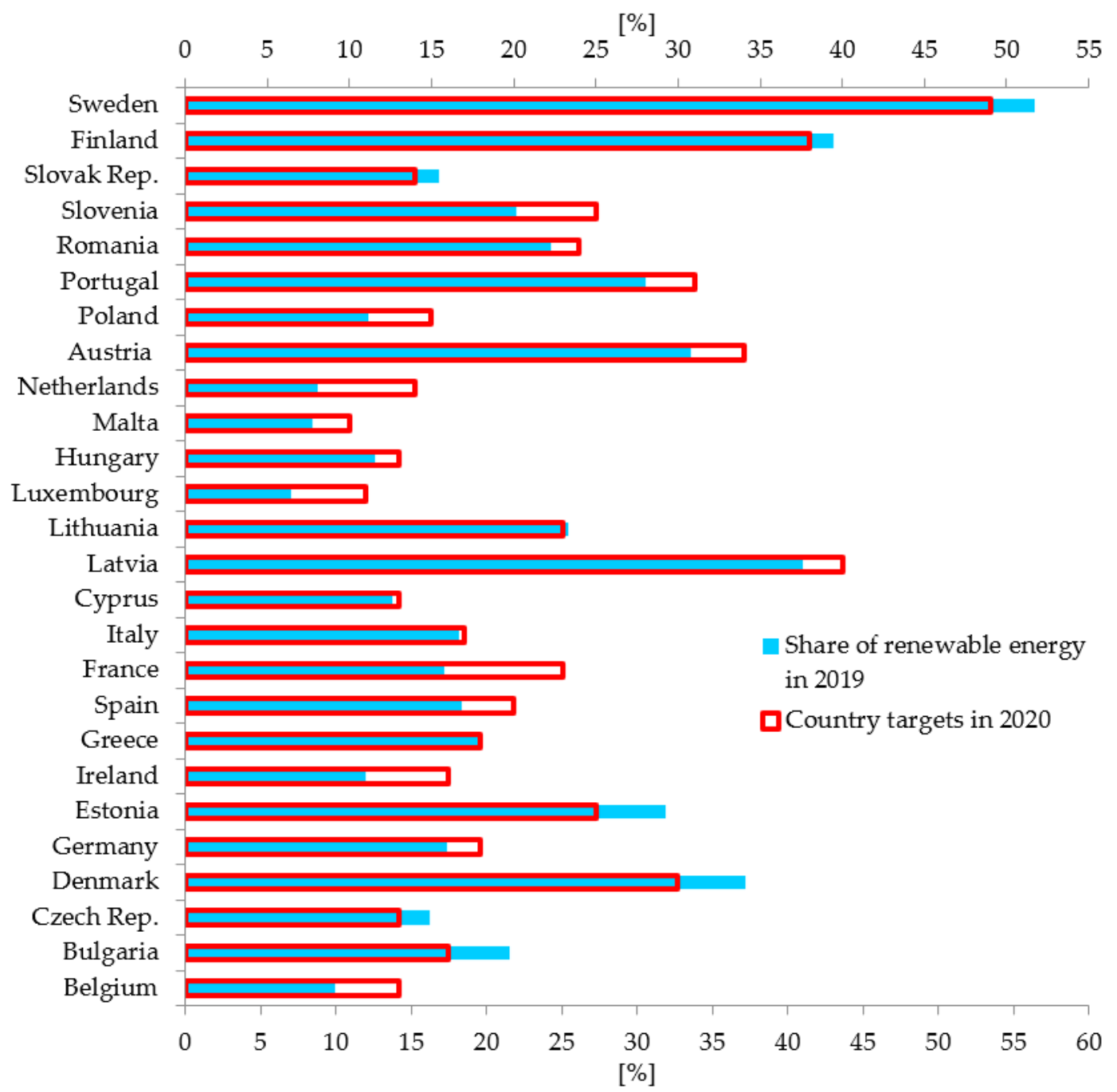

Figure 2. Share of renewable energy sources in European Union and targets for 2020. Adapted from Ref. [4].

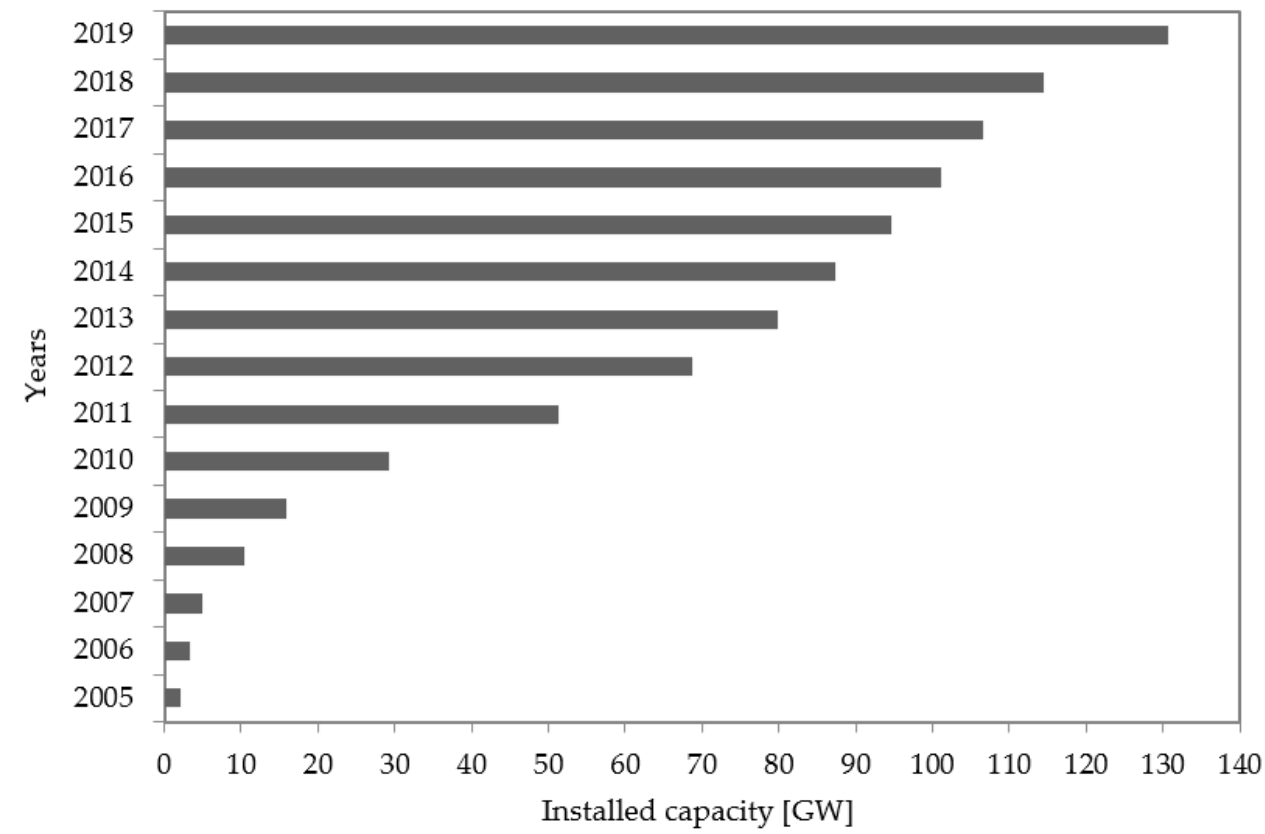

Figure 3. Photovoltaic installed capacity in Europe. Adapted from Ref. [4]. 
The total photovoltaic installed capacity in the EU countries is $130.67 \mathrm{GW}$ in 2019 . The largest installed capacity is in Germany with $49 \mathrm{GW}$, which accounts for almost 38\% of the total energy in photovoltaic installations in the European Union [19-21]. Despite the growing interest in photovoltaics in the EU Member States, almost $80 \%$ of the installed capacity belongs to only five countries: Germany, Italy, Great Britain, France and Spain.

The nominal operation of a photovoltaic installation depends on the available quantity of solar energy. The availability of the insolation energy is governed by many atmospheric parameters such as, the sun azimuth angle, ambient temperature, air-carried dust and clouds. An indicator specifying the random nature of the clouds effect is taken into account, as it directly affects the level of the solar energy received by the photovoltaic panels [22,23].

The performance analysis of a specific photovoltaic installation requires the creation of a set of dedicated models to describe different functions in the installation [24-26]. A photovoltaic installation usually consists of: photovoltaic panels, an inverter and power electronics systems that control the installation operation [27-29]. Since the output power of a PV installation depends on the random nature of the clouds effect, the installation cannot be represented by static two-state or multi-state models, as these models assume a constant value of the generated power [30]. One of the primary errors in designing photovoltaic installations comes from the lack of the load-bearing roof or the geological soil expertise, depending on whether it is a roof or ground-mounted installation. This results in a decrease in the structure strength and exposes the installation structure to damage. Another error in design is due to the lack of an extensive analysis of the shading effects from neighbouring objects on the installation. Shading of even a small area can shut down part of the installation.

For the design of photovoltaic installations, numerical simulation is largely used. It enables designers to predict the electrical energy production and to optimise the installation design [31]. Numerical simulation uses a variety of software and big databases that contain regional operational insolation data over many years. Computer simulations can also prevent design errors that are the major causes of almost all the failure modes like installation fire, anormal operation conditions or cable insulation damage [32,33].

The paper describes, in Section 1, the general lines of the methodology of the study.

In Section 2, the paper presents a general description of the study area.

In Section 3, the paper presents identification and technical description of the photovoltaic installation and its simulations.

In Section 4, the paper presents the principal conclusions and synthesis of the comparative assessment of the estimated and the real measured electrical production of an operational photovoltaic installation.

\section{Description of Study Area}

The distinguished installation is located in Subcarpathian province, Poland. The commune is located on the right bank of the Vistula, in the south-eastern part of Poland, it covers a total area of 921 square kilometres and lies in $50^{\circ} 05^{\prime} 08.0^{\prime \prime} \mathrm{N}$ and $22^{\circ} 01^{\prime} 52.7^{\prime \prime} \mathrm{E}$ as shown in the Figure 4. Commune has an urbanisation rate of 233 inhabitant $/ \mathrm{km}^{2}$ and is laid of 200 MASL. The area of the commune is dominated by arable lands, which constitutes as much as $65 \%$ of the city's area and forest land is about $13 \%$. The rest of the area is occupied by urban areas and industrial areas. The city is located in the climatic zone of lowlands and sub montane foothills. This area is characterised by hot summers, relatively small amounts of rainfall of about $600 \mathrm{~mm}$ and not severe winter. 


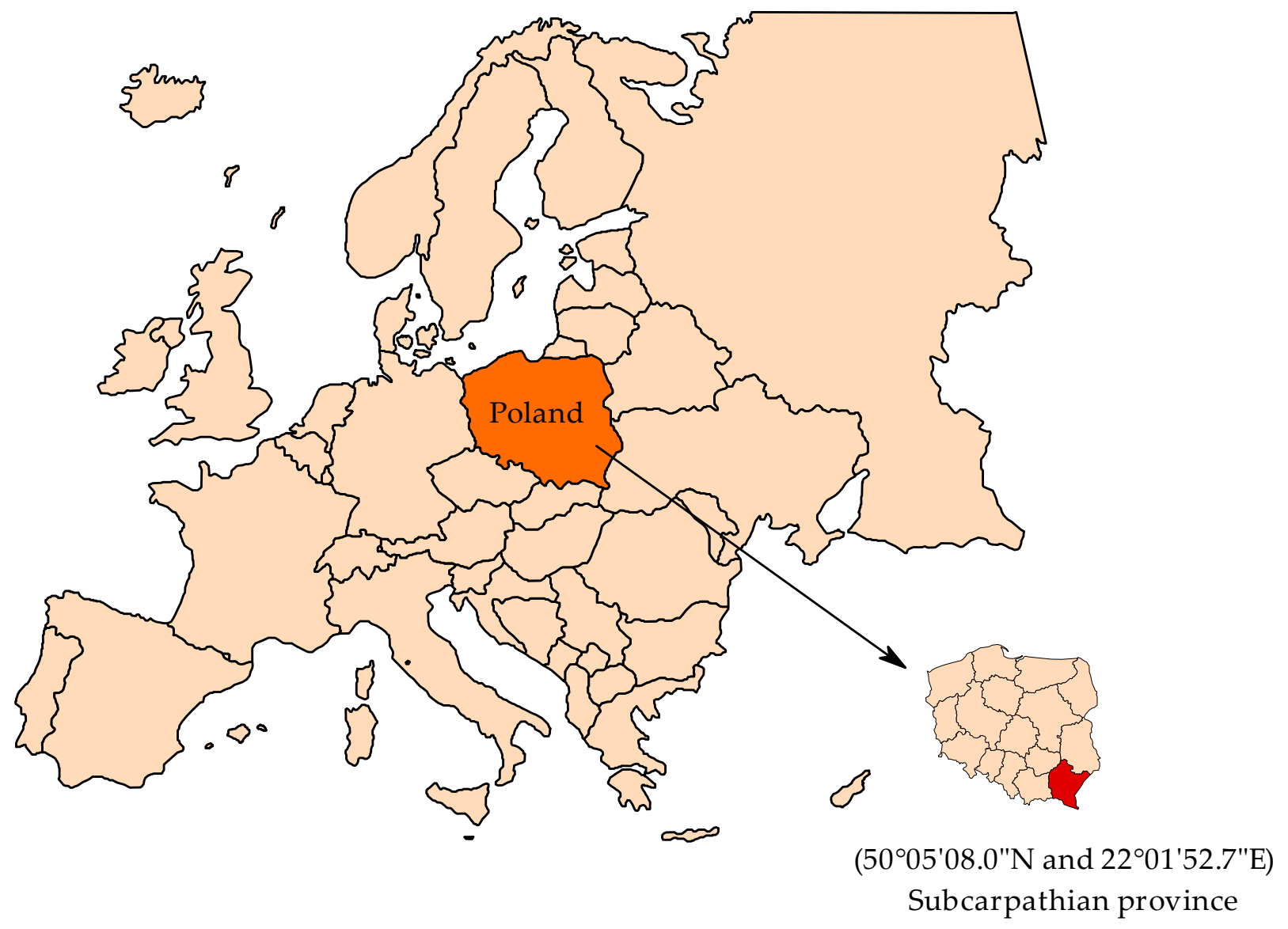

Figure 4. Location of the examined installation: Subcarpathian province, Poland $\left(50^{\circ} 05^{\prime} 08.0^{\prime \prime} \mathrm{N}\right.$ and $\left.22^{\circ} 01^{\prime} 52.7^{\prime \prime} \mathrm{E}\right)$.

\section{Photovoltaic Installation Simulations}

The design of the photovoltaic installation requires, first, to choose whether the installation will be connected to the grid or not. The designed installation will be connected to the low voltage grid through a bidirectional meter, which enables the surplus of energy to be transferred to the power grid. The next step is to determine the exact location of the installation. On this basis, the program selects the insolation values corresponding to the location. In the next step, you can choose whether the installation will have an energy storage in the form of batteries that will store the energy surplus. In the designed installation, the surplus will be transferred to the grid, therefore the installation will not have an energy storage. In the next stage, you need to create a building model, select photovoltaic panels, determine their slope and select an appropriate inverter. At the design stage, attention should be paid to whether there are any objects on the roof or in the vicinity of the building that could shade the installation. This can have a significant impact on the installation efficiency. After the simulation is completed, the program presents the detailed results regarding the installation efficiency, shading effects and energy losses.

A photovoltaic installation was designed for an office building located in south-eastern Poland. It consists of 16 panels with a capacity of $265 \mathrm{Wp}$, giving a total output power of $4.24 \mathrm{kWp}$. The BlueSol software was used to perform the simulation.

Figure 5 shows the values of insolation for the location of the designed building, on the basis of which the program calculates the energy produced by the photovoltaic panels. The data source is the NASA-SSE database. The NASA database is based on measurements over a period of 22 years, in the years 1983-2005. 


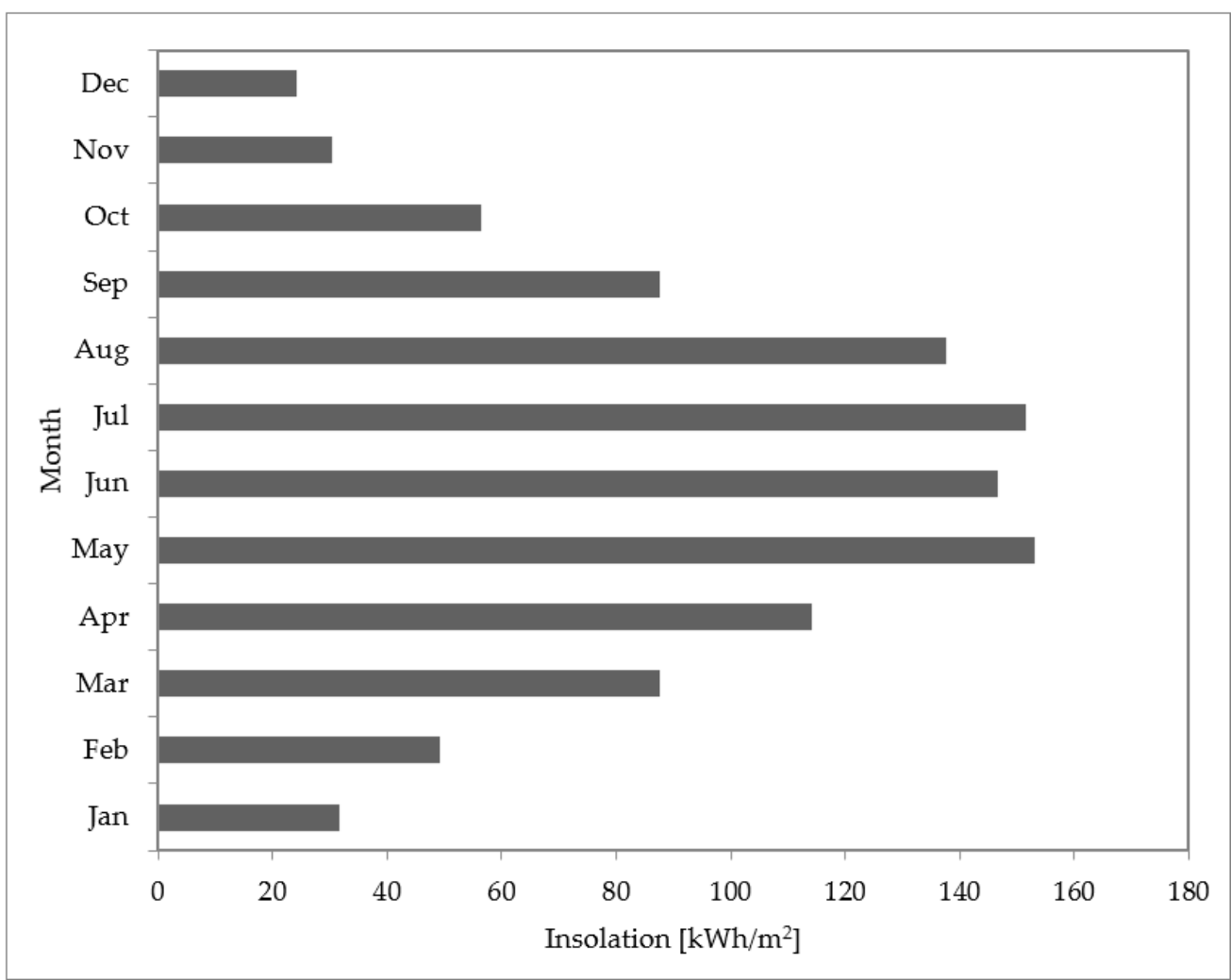

Figure 5. Insolation in individual months based on the NASA-SSE database.

Taking into account the average daily intensity of solar radiation and the number of days in a year, the program determined total annual insolation as $1070 \mathrm{kWh} / \mathrm{m}^{2}$. The highest value of insolation was in May and amounts to $153.14 \mathrm{kWh} / \mathrm{m}^{2}$, while the lowest value was in December and amounts to $24.18 \mathrm{kWh} / \mathrm{m}^{2}$.

Figure 6 shows the designed installation as described in the BlueSol program. Due to the flat roof, the photovoltaic panels are designed on metal structures at an angle of 13 degrees.

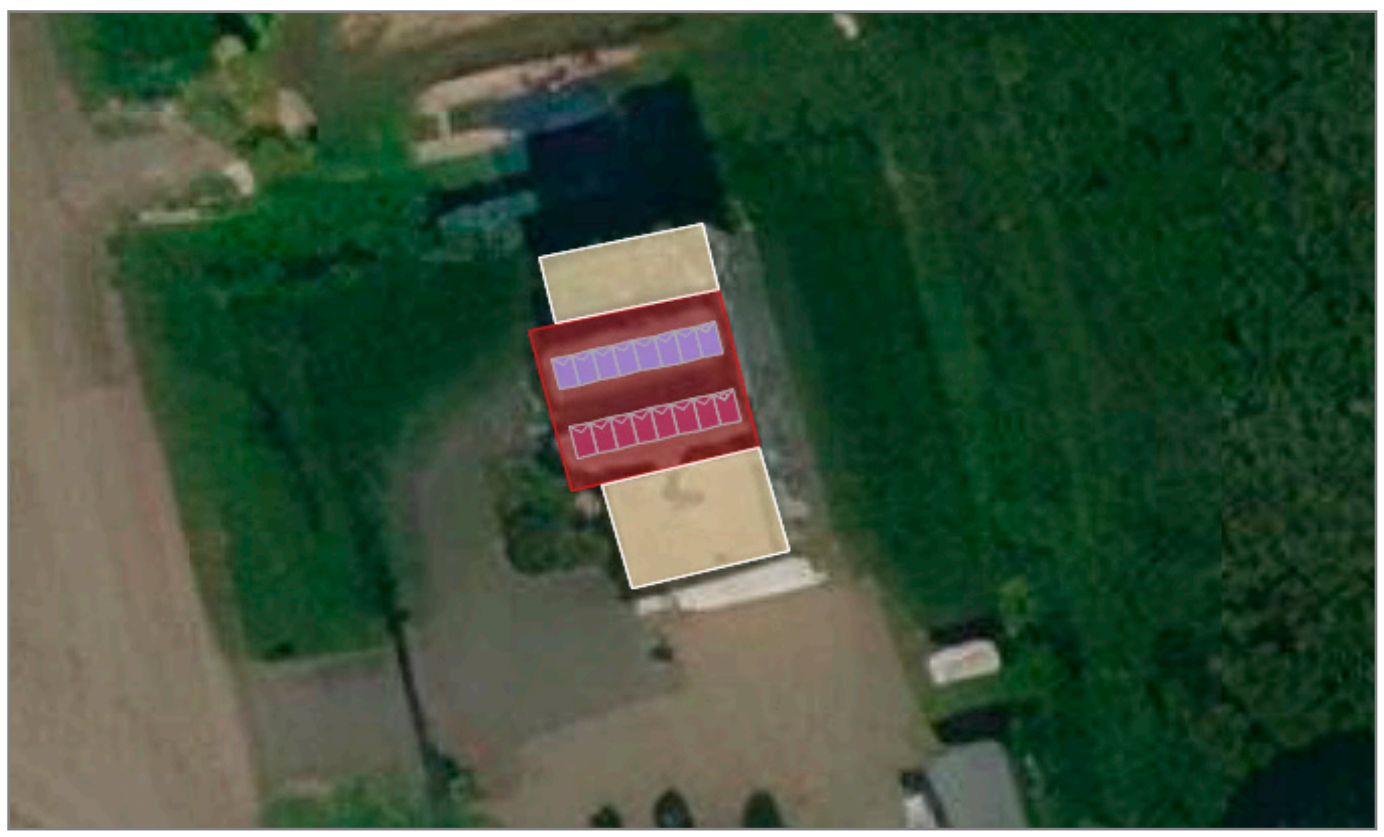

Figure 6. Model of the designed installation. 
Figure 7 shows the azimuth of the designed building and the path of the sun (blue line), which shows the altitude of the sun during the year, which makes it possible to calculate the shading of the installation by neighbouring buildings, trees, or chimneys.

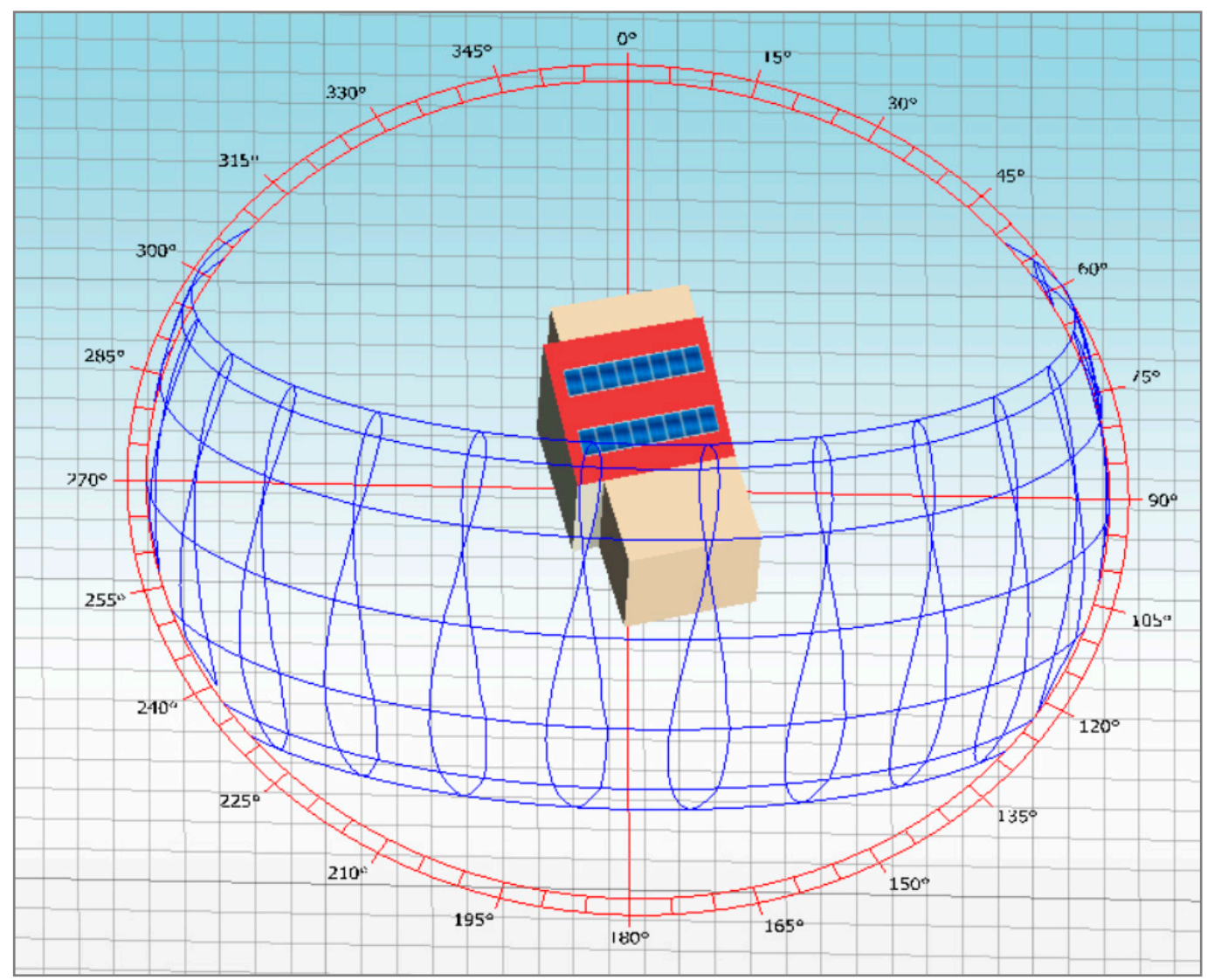

Figure 7. Sun path and building azimuth.

Based on the design, simulations were performed. Figure 8 shows the monthly energy production calculated by the program BlueSol.

The total energy obtained during the year is $4244.8 \mathrm{kWh}$. The energy obtained from one $\mathrm{kWp}$ of installed capacity is $1001.1 \mathrm{kWh} / \mathrm{kWp}$. The largest energy production takes place in May and amounts up to $578.7 \mathrm{kWh}$, while the least produced energy is in December and goes down to $114.9 \mathrm{kWh}$.

After designing the photovoltaic system and simulation, the installation was performed on the building.

Figure 9 shows pictures of the completed installation.

The installation was realised in 2019 , with a total insolation surface of $26.24 \mathrm{~m}^{2}$. Measurements of the produced electrical energy were carried out throughout 2020 (Figure 10).

The total energy produced in 2020 was $4810.5 \mathrm{kWh}$. Converted to one $\mathrm{kWp}$ of installed power, the production amounted to $1134.5 \mathrm{kWh} / \mathrm{kWp}$. Compared to the simulation expectations, the amount of the produced energy is higher by $13 \%(565.7 \mathrm{kWh}$ more than in simulations).

Figure 11 shows the results of solar radiation measurements in individual months of 2020, carried out by the SolarAOT radiation transfer research station located in southeastern Poland [34].

The seasonal variations in the installation conversion rate are shown in Figure 12. The energy conversion ratio is an indicator of the thermal performance of the installation. 


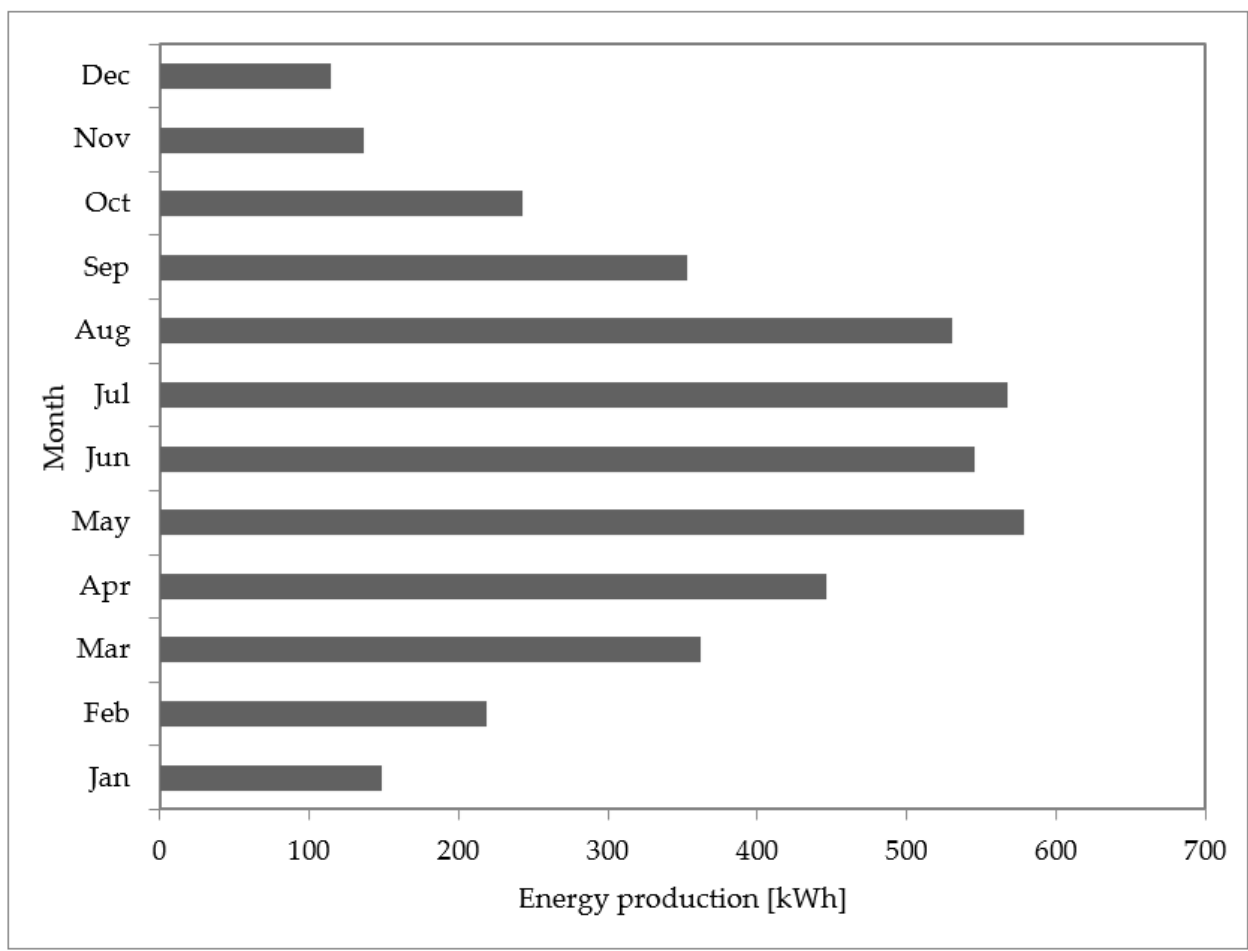

Figure 8. Electricity production in individual months.

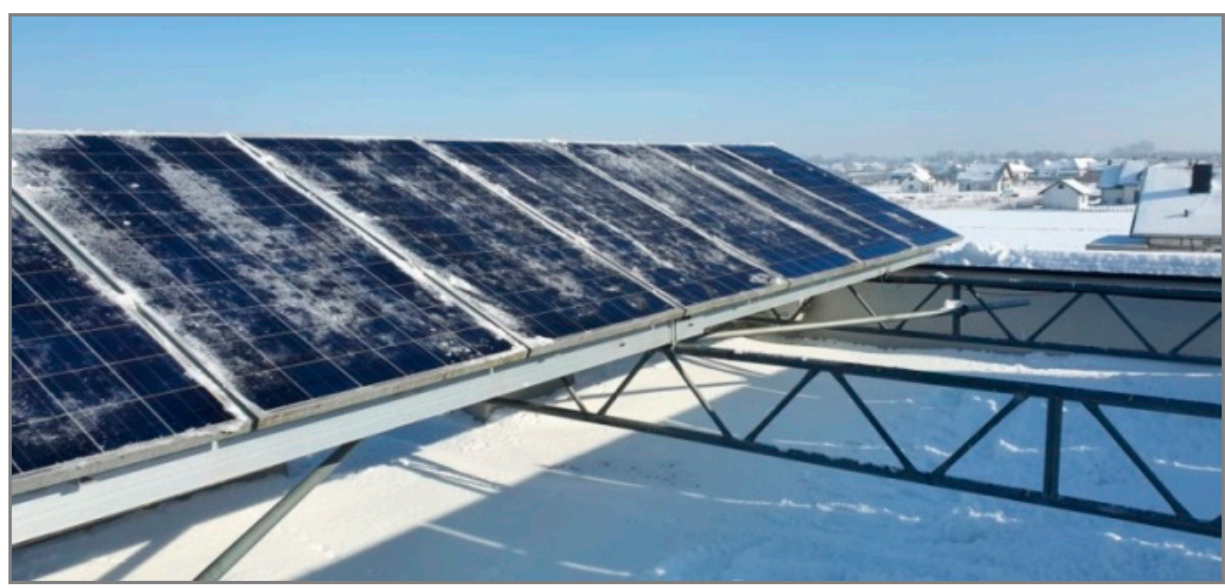

(a)

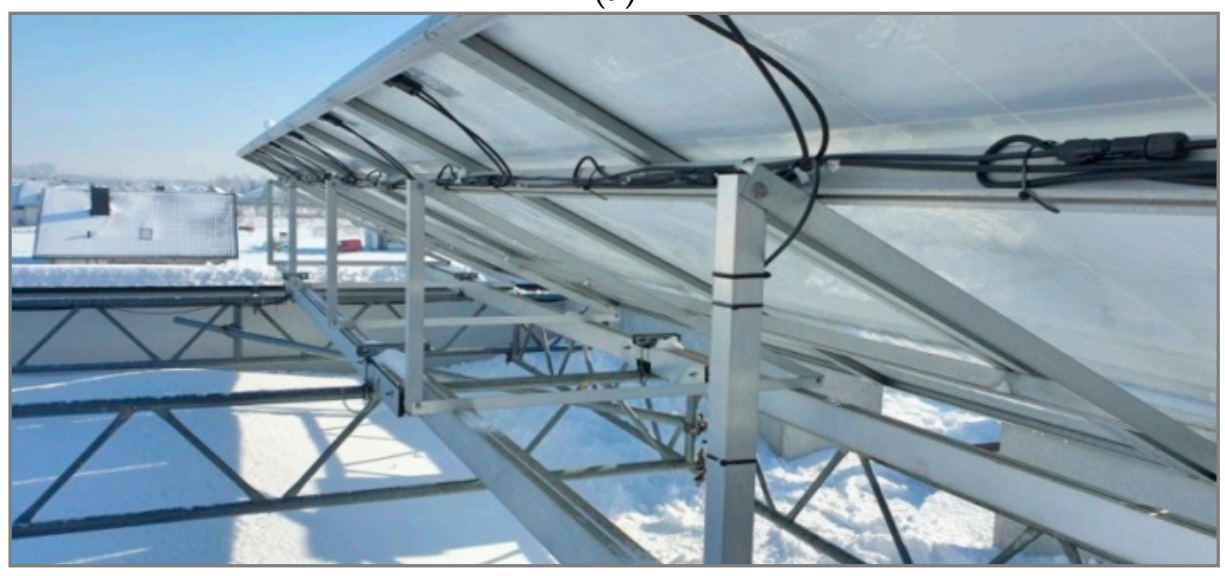

(b)

Figure 9. Cont. 


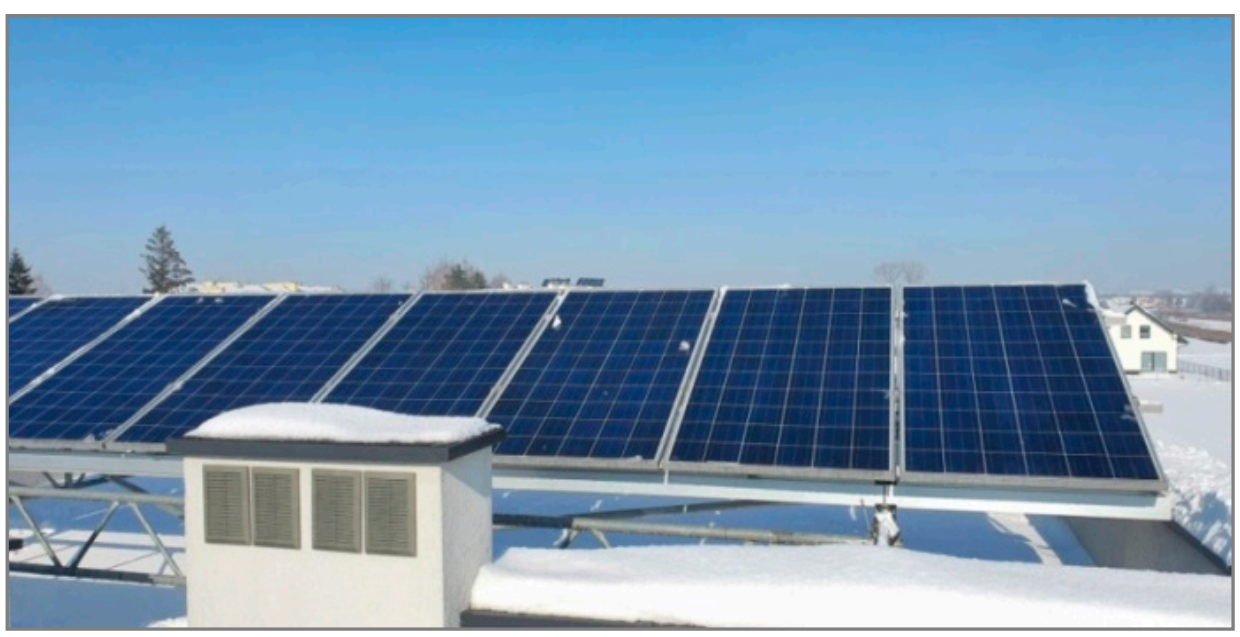

(c)

Figure 9. Photovoltaic installation on the building: (a-c) solar PV panels.

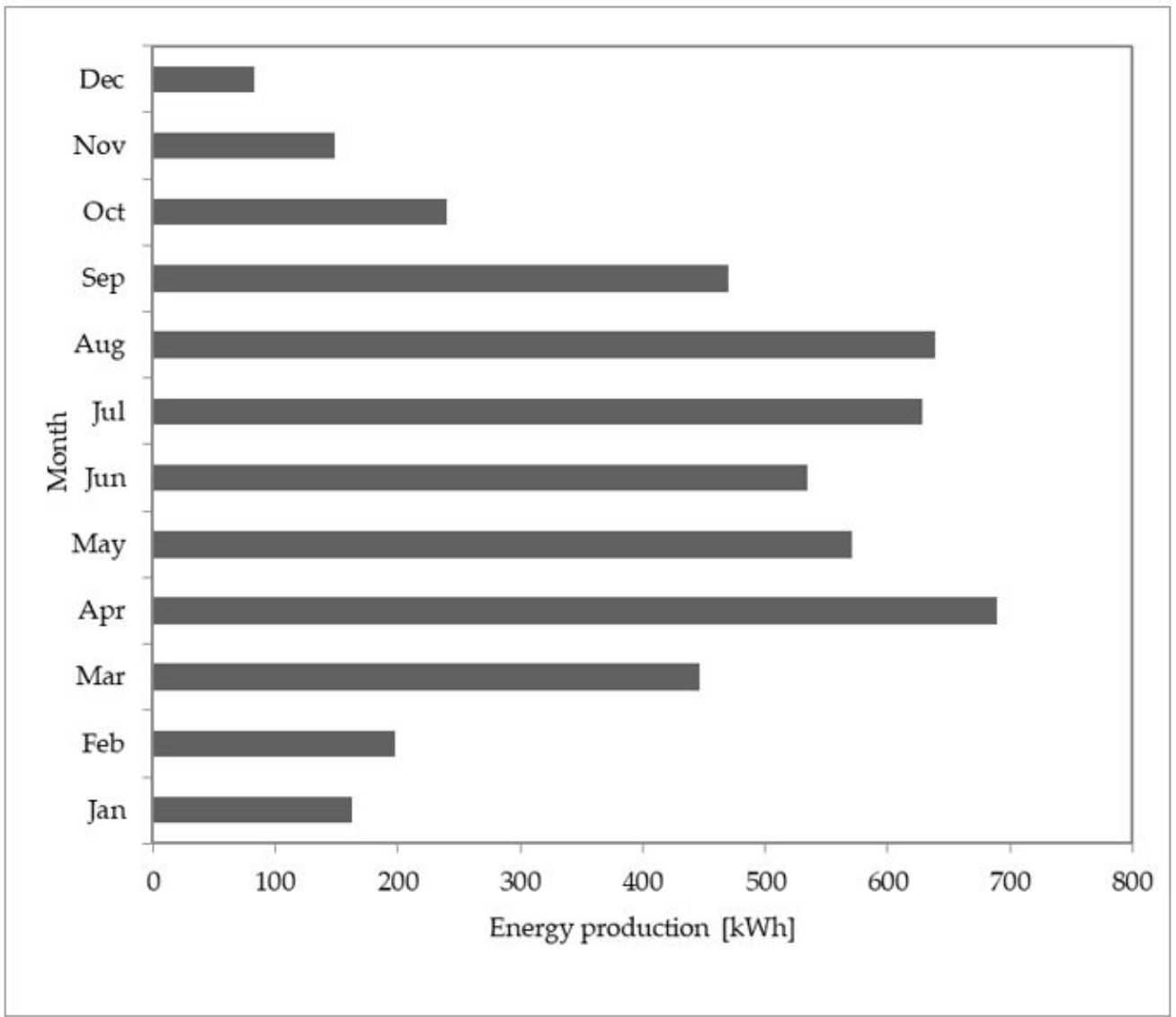

Figure 10. Actual energy production by the photovoltaic installation in 2020.

Figure 12 proves that the energy conversion ratio is not constant all over the year. It seems as if insolation power and seasons impact the installation performance measured through the energy conversion ratio. As can be noticed that the lower is the insolation power, higher is the conversion ratio.

The total annual insolation in 2020 was $1198.12 \mathrm{kWh} / \mathrm{m}^{2}$, which is $12 \%$ higher than the data given in the NASA-SSE database. 


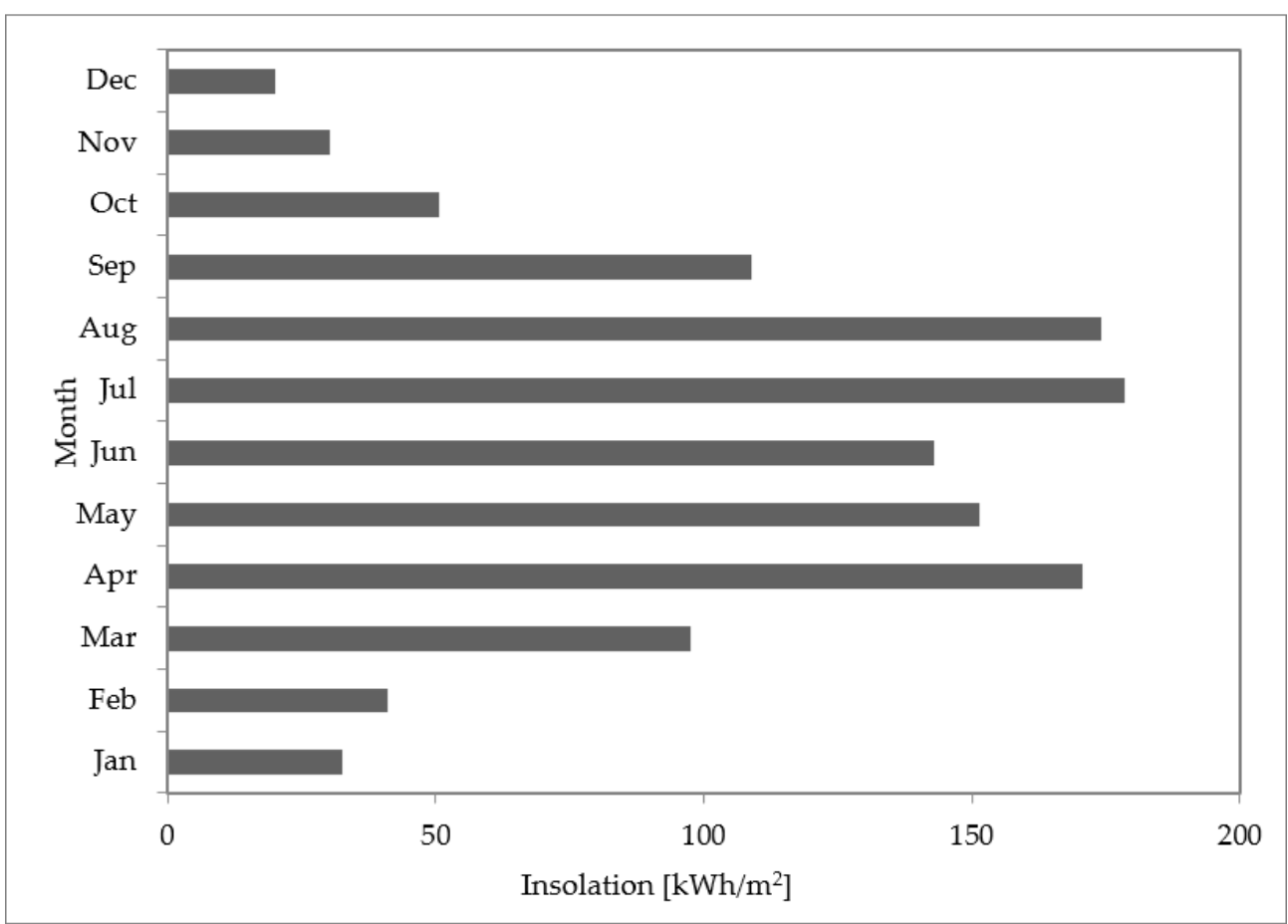

Figure 11. Insolation in individual months of 2020 based on measurements from the SolarAOT station.

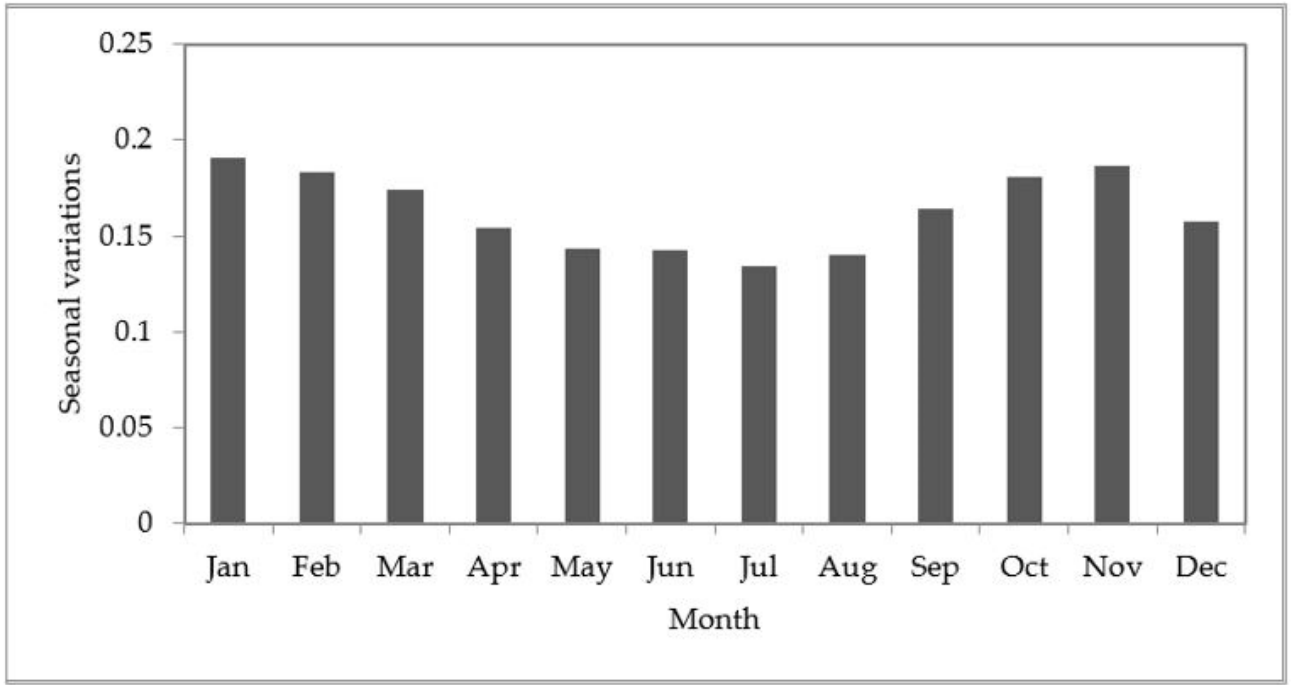

Figure 12. The variation of the installation energy conversion rate with the seasons.

It is also possible to calculate the approximate electricity production of a photovoltaic installation without the need for expensive simulation software. Produced energy can be calculated from the formula:

$$
E=\frac{N \cdot k \cdot P_{P V} \cdot W}{S T C}(\mathrm{kWh})
$$

where: $N$-insolation on a horizontal surface $\left(\mathrm{kWh} / \mathrm{m}^{2}\right), k$-a correction factor that allows the insolation to be converted from a horizontal position to an inclined surface (for an inclination of the panels of $13^{\circ}$, and an inclination from the south of $15^{\circ}, k=1.09$ ), $P_{P V}$ - photovoltaic installation power, $W$-performance ratio, $S T C$ - standard test conditions, $\mathrm{STC}=1000 \mathrm{~W} / \mathrm{m}^{2}$. 
The performance ratio determines the level of losses in the photovoltaic installation. Table 1 shows the losses in the installation determined with the BlueSol program.

Table 1. Losses in the analysed photovoltaic installation.

\begin{tabular}{cc}
\hline Type of Losses & Loss Value (\%) \\
\hline Heat losses & 3.00 \\
Losses from mismatch & 2.00 \\
Resistance Ohmic losses & 4.00 \\
DC / AC conversion losses & 2.70 \\
Other losses & 2.00 \\
Total losses & 13.70 \\
\hline
\end{tabular}

Based on solar irradiation data from the NASA database and the results of solar irradiation measurements (SolarAOT) in 2020, produced energy were recalculated using the formula (1) as shown in example below.

For insolation on a horizontal surface $N=32.64 \mathrm{kWh} / \mathrm{m}^{2}$ (January), $k=1.09$, photovoltaic installation power $P_{P V}=4.24 \mathrm{kWp}$, performance ratio $W=0.863$ and $S T C=1000 \mathrm{~W} / \mathrm{m}^{2}$, produced energy calculated from the formula 1 equals:

$$
E=\frac{N \cdot k \cdot P_{P V} \cdot W}{S T C}=\frac{32.64 \cdot 1.09 \cdot 4240 \cdot 0.863}{1000}=130.2 \mathrm{kWh}
$$

The results are shown in Table 2.

Table 2. Electricity yield from the analysed photovoltaic installation.

\begin{tabular}{ccccc}
\hline Month & $\begin{array}{c}\text { Actual Energy } \\
\text { Production }\end{array}$ & $\begin{array}{c}\text { BlueSol } \\
\text { Software }\end{array}$ & $\begin{array}{c}\text { Calculations Using Formula (1) } \\
\text { for Insolation from } \\
\text { Measurements }\end{array}$ & $\begin{array}{c}\text { Calculations Using Formula (1) } \\
\text { for Insolation from NASA } \\
\text { Database }\end{array}$ \\
\hline $\mathbf{( - )}$ & $\mathbf{( k W h )}$ & $\mathbf{( k W h )}$ & $\mathbf{( k W h )}$ & $\mathbf{( k W h )}$ \\
\hline Jan & 163.2 & 148.3 & 130.2 & 126.1 \\
Feb & 197.4 & 219.3 & 163.4 & 196.6 \\
Mar & 446.1 & 361.8 & 388.6 & 349.9 \\
Apr & 689.6 & 446.1 & 680.2 & 455.9 \\
May & 570.5 & 578.7 & 603.9 & 610.8 \\
Jun & 534.3 & 545.6 & 570.0 & 585.1 \\
Jul & 628.7 & 567.5 & 711.3 & 604.6 \\
Aug & 639.1 & 530.8 & 694.2 & 549.0 \\
Sep & 470.4 & 352.7 & 434.5 & 349.4 \\
Oct & 240.1 & 242.9 & 201.7 & 225.0 \\
Nov & 148.3 & 136.2 & 120.8 & 120.8 \\
Dec & 82.8 & 114.9 & 79.7 & 96.4 \\
Total & 4810.5 & 4244.8 & 4778.6 & 4269.6 \\
\hline
\end{tabular}

A comparison of the value of insolation and electricity production is shown. Using formula (1), it is possible to calculate the energy production during the year with high accuracy, without the need to use specialised software. The difference between the solar calculations from NASA's database and the PV installation design software is $24.8 \mathrm{kWh}$ per year, which is a difference of $0.6 \%$. In the case of calculations using data from measurements at the research station for 2020, the calculated annual energy produced is lower by $31.9 \mathrm{kWh}$ compared to the actual data, which is a difference of $0.66 \%$, as shown in the Figures 13 and 14.

Based on the results obtained from the measurements of the amount of energy produced from a photovoltaic installation, it can be concluded that the results obtained from simulation programs and calculations using NASA-SSE databases may differ significantly from the real values. The discrepancy between analytical and experimental data can be 
caused by the rapidly changing climate, which is difficult to predict in a given year, and the relatively low resolution of insolation measurements, which results in simulation programs assuming the same values even for remote locations whose weather conditions may be different, e.g., due to different topography. In the analysed cases, it is a difference of $13 \%$ in the amount of electricity produced.

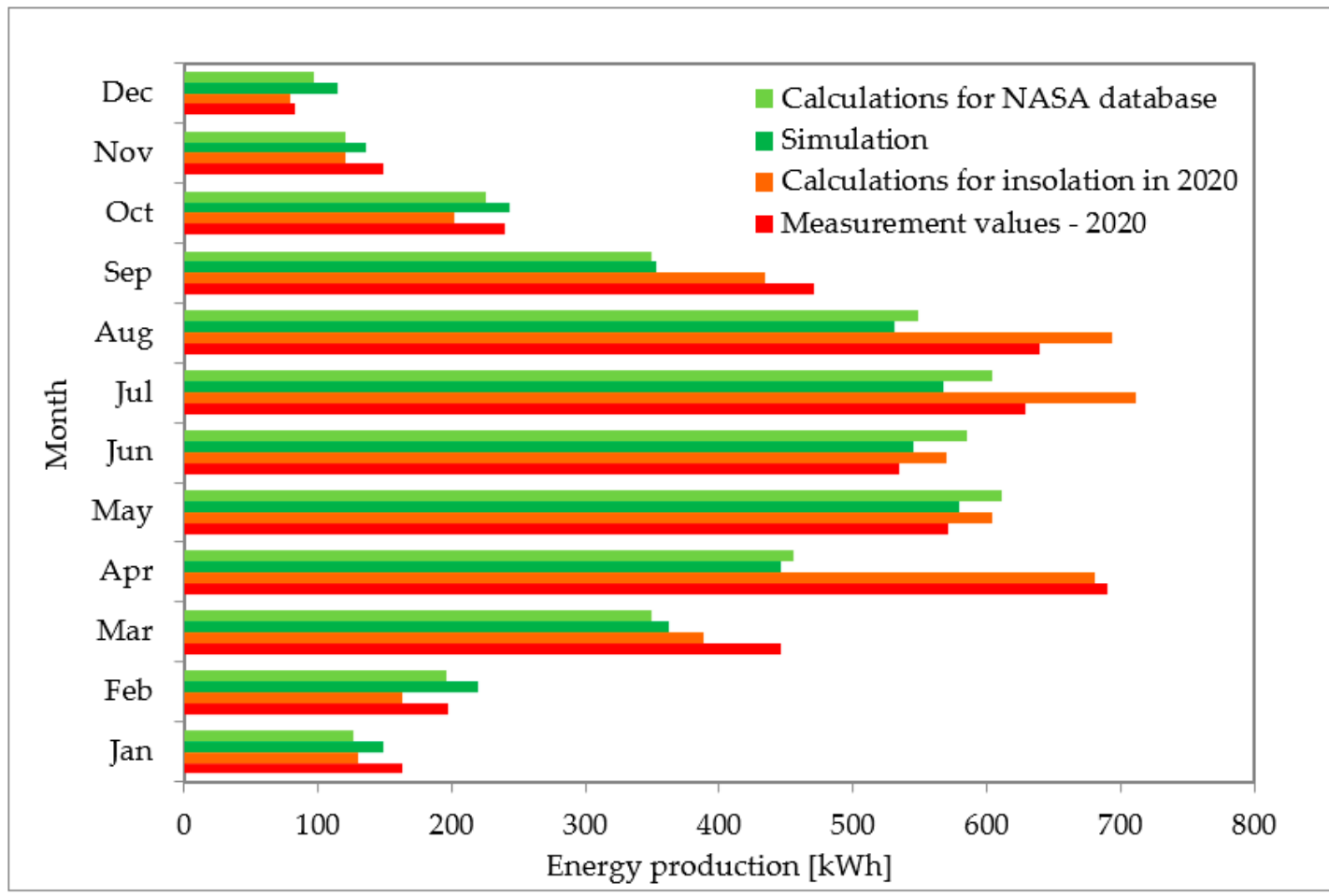

Figure 13. Monthly energy production over a year.

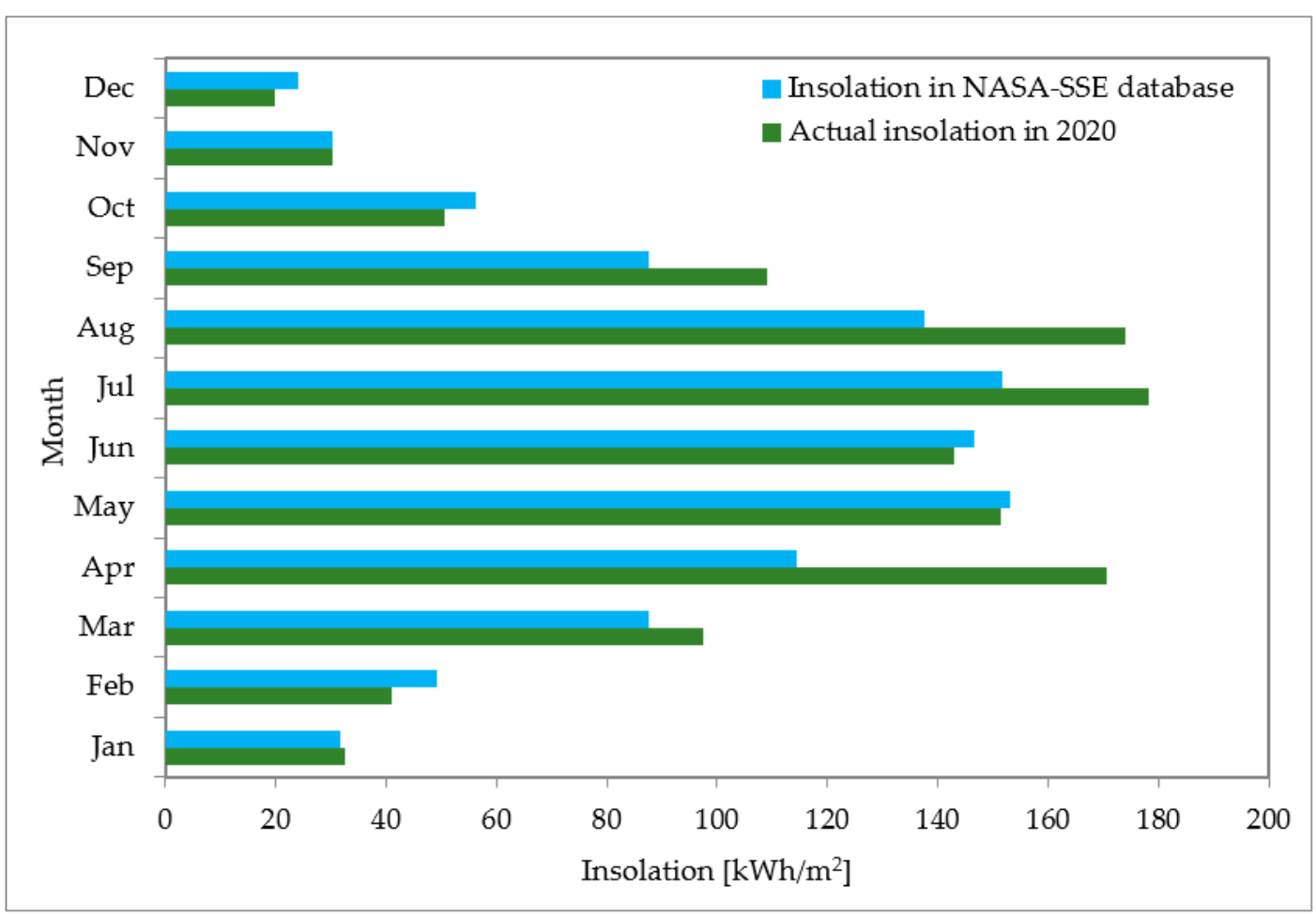

Figure 14. Insolation measured by SolarAOT and NASA-SSE database. 


\section{Conclusions}

Currently, the photovoltaic energy market is one of the fastest growing renewable energy markets in Europe and in the world. The development of the market was influenced by many factors, including international legal restrictive regulations on greenhouse gas emissions, the increase of the prices of the traditional energy sources, as well as the increase in subsidies for renewable energy projects and the growing ecological awareness of the society.

The use of numerical simulation allows optimising the design of a photovoltaic installation and take into account the influence of neighbouring objects or trees on the shading of the panels, the influence of the tilt angle and the selection of all installation elements.

Based on the results obtained from measurements of the amount of energy produced from a photovoltaic installation, it can be concluded that the results obtained from simulation programs and calculations using NASA-SSE databases may differ significantly from the real values. In the analysed cases, it is a difference of $13 \%$ in the amount of electricity produced.

It should also be noted that the databases used by the programs are based on the results of measurements between 1983-2005 [35]. Due to the changing climate, more up-todate databases should be used that would allow more precise determination of electricity production from solar cells.

The analysis of failures shows that the photovoltaic companies have to take action to prevent and improve the technical conditions of PV installation operation. Further investigations should be performed for other available databases and measurements for the following years in order to compare the accuracy of other databases. Future work will also include reliability analysis of actual installation as well as decrease the performance of panels with age. The presented analysis constitutes a first step in assessing the risk due to these second family of failures related to solar-energy nature and could be considered as a tool to support decision-making in the process of designing photovoltaic installations and analysing the economic efficiency of investments.

Author Contributions: All authors equally contributed to the development of this manuscript. All authors have read and agreed to the published version of the manuscript.

Funding: This research received no external funding.

Institutional Review Board Statement: Not applicable.

Informed Consent Statement: Not applicable.

Data Availability Statement: Not applicable.

Conflicts of Interest: The authors declare no conflict of interest.

\section{References}

1. Włodarczyk, B.; Firoiu, D.; Ionescu, G.; Ghiocel, F.; Szturo, M.; Markowski, L. Assessing the Sustainable Development and Renewable Energy Sources Relationship in EU Countries. Energies 2021, 14, 2323. [CrossRef]

2. Marks-Bielska, R.; Bielski, S.; Pik, K.; Kurowska, K. The Importance of Renewable Energy Sources in Poland's Energy Mix. Energies 2020, 13, 4624. [CrossRef]

3. Damm, A.; Köberl, J.; Prettenthaler, F.; Rogler, N.; Töglhofer, C. Impacts of $+2{ }^{\circ} \mathrm{C}$ global warming on electricity demand in Europe. Clim. Serv. 2017, 7, 12-30. [CrossRef]

4. Ec.Europa.Eu/Eurostat. 2020 Climate \& Energy Package. Available online: https://ec.europa.eu/clima/eu-action/climatestrategies-targets/2020-climate-energy-package_en (accessed on 20 May 2021).

5. Ec.Europa.Eu/Eurostat. Climate Action. Available online: https://Ec.Europa.Eu/Clima/Policies/Strategies/2020_en (accessed on 26 May 2021).

6. Nowak, K.; Rabczak, S. Co-Combustion of Biomass with Coal in Grate Water Boilers at Low Load Boiler Operation. Energies 2021, 14, 2520. [CrossRef]

7. Singh, K.; Singh, S.; Kandpal, D.C.; Kumar, R. Experimental performance study of photovoltaic solar panel with and without water circulation. Mater. Today Proc. 2021, 46, 6822-6827. [CrossRef] 
8. Tian, L.; Huang, Y.; Liu, S.; Sun, S.; Deng, J.; Zhao, H. Application of photovoltaic power generation in rail transit power supply system under the background of energy low carbon transformation. Alex. Eng. J. 2021, 60, 5167-5174. [CrossRef]

9. Fernández-González, R.; Arce, E.; Garza-Gil, D. How political decisions affect the economy of a sector: The example of photovoltaic energy in Spain. Energy Rep. 2021, 7, 2940-2949. [CrossRef]

10. Liang, S.; Zheng, H.; Ma, X.; Liu, F.; Wang, G.; Zhao, Z. Study on a passive concentrating photovoltaic-membrane distillation integrated system. Energy Convers. Manag. 2021, 242, 114332. [CrossRef]

11. Klein, M.; Deissenroth, M. When do households invest in solar photovoltaics? An application of prospect theory. Energy Policy 2017, 109, 270-278. [CrossRef]

12. Srinivasan, S.; Kottam, V.K.R. Solar photovoltaic module production: Environmental footprint, management horizons and investor goodwill. Renew. Sustain. Energy Rev. 2018, 81, 874-882. [CrossRef]

13. Awerbuch, S. Investing in photovoltaics: Risk, accounting and the value of new technology. Energy Policy 2000, 28, 1023-1035. [CrossRef]

14. Buragohain, S.; Mohanty, K.; Mahanta, P. Hybridization of solar photovoltaic and biogas system: Experimental, economic and environmental analysis. Sustain. Energy Technol. Assess. 2021, 45, 101050. [CrossRef]

15. Sharma, D.; Mehra, R.; Raj, B. Comparative analysis of photovoltaic technologies for high efficiency solar cell design. Superlattices Microstruct. 2021, 153, 106861. [CrossRef]

16. Kirthika, B.; Sekar, S.; Saravanan, S.; Shivasankaran, N.; Balan, A.; Kalirajan, M. Performance analysis of synthesized ZnO nanoparticles coated photovoltaic cell. Mater. Today Proc. 2020, 21, 511-513. [CrossRef]

17. Nayak, P.K.; Mahesh, S.; Snaith, H.J.; Cahen, D. Photovoltaic solar cell technologies: Analysing the state of the art. Nat. Rev. Mater. 2019, 4, 269-285. [CrossRef]

18. Sarasa-Maestro, C.J.; Dufo-López, R.; Bernal-Agustín, J.L. Photovoltaic remuneration policies in the European Union. Energy Policy 2013, 55, 317-328. [CrossRef]

19. García-Álvarez, M.T.; Cabeza-García, L.; Soares, I. Assessment of energy policies to promote photovoltaic generation in the European Union. Energy 2018, 151, 864-874. [CrossRef]

20. Arantegui, R.L.; Jäger-Waldau, A. Photovoltaics and wind status in the European Union after the Paris Agreement. Renew. Sustain. Energy Rev. 2018, 81, 2460-2471. [CrossRef]

21. Bódis, K.; Kougias, I.; Jäger-Waldau, A.; Taylor, N.; Szabó, S. A high-resolution geospatial assessment of the rooftop solar photovoltaic potential in the European Union. Renew. Sustain. Energy Rev. 2019, 114. [CrossRef]

22. Paska, J.; Piotr, M. Modelowanie Niezawodności Elektrowni Fotowoltaicznych. Rynek Energii 2014, 111, 81-86.

23. Anand, B.; Shankar, R.; Murugavelh, S.; Rivera, W.; Prasad, K.M.; Nagarajan, R. A review on solar photovoltaic thermal integrated desalination technologies. Renew. Sustain. Energy Rev. 2021, 141, 110787. [CrossRef]

24. Chai, Q.; Zhang, C.; Dong, Z.Y.; Xu, Y. Operational reliability assessment of photovoltaic inverters considering voltage/VAR control function. Electr. Power Syst. Res. 2020, 190, 106706. [CrossRef]

25. Raghuwanshi, S.S.; Arya, R. Reliability evaluation of stand-alone hybrid photovoltaic energy system for rural healthcare centre. Sustain. Energy Technol. Assess. 2020, 37, 100624. [CrossRef]

26. Duarte, F.; Torres, J.; Baptista, A.; Lameirinhas, R.M. Optical Nanoantennas for Photovoltaic Applications. Nanomaterials 2021, 11, 422. [CrossRef] [PubMed]

27. Van De Sande, W.; Ravyts, S.; Sangwongwanich, A.; Manganiello, P.; Yang, Y.; Blaabjerg, F.; Driesen, J.; Daenen, M. A mission profile-based reliability analysis framework for photovoltaic DC-DC converters. Microelectron. Reliab. 2019, 100-101, 113383. [CrossRef]

28. Jacob, A.S.; Banerjee, R.; Ghosh, P.C. Trade-off between end of life of battery and reliability in a photovoltaic system. J. Energy Storage 2020, 30, 101565. [CrossRef]

29. Satpathy, P.R.; Sharma, R. Reliability and losses investigation of photovoltaic power generators during partial shading. Energy Convers. Manag. 2020, 223, 113480. [CrossRef]

30. Sun, Y.; Gao, J.; Wang, J.; Huang, Z.; Li, G.; Zhou, M. Evaluating the reliability of distributed photovoltaic energy system and storage against household blackout. Glob. Energy Interconnect. 2021, 4, 18-27. [CrossRef]

31. Kut, P.; Nowak, K. Design of Photovoltaic Systems using Computer Software. J. Ecol. Eng. 2019, 20, 72-78. [CrossRef]

32. Zuniga-Reyes, M.-A.; Robles-Ocampo, J.-B.; Sevilla-Camacho, P.-Y.; Rodriguez-Resendiz, J.; Lastres-Danguillecourt, O.; CondeDiaz, J.-E. Photovoltaic Failure Detection Based on String-Inverter Voltage and Current Signals. IEEE Access 2021, 9, 39939-39954. [CrossRef]

33. Luo, W.; Clement, C.E.; Khoo, Y.S.; Wang, Y.; Khaing, A.M.; Reindl, T.; Kumar, A.; Pravettoni, M. Photovoltaic module failures after 10 years of operation in the tropics. Renew. Energy 2021, 177, 327-335. [CrossRef]

34. Aerosol and Radiation Observatory. Available online: https://Www.Igf.Fuw.Edu.Pl/ \{\}kmark/Stacja/Stacja_info.Php (accessed on 15 May 2021).

35. Tatarczak, J.; Sokołowska, M.; Olchowik, J.M. Analiza napromieniowania słonecznego Polski na podstawie danych satelitarnych NASA. J. Civ. Eng. Environ. Arch. 2015, 32, 505-518. [CrossRef] 